\title{
Case study of the Vernavola Stream (sub-lacustrine Ticino River basin, Northern Italy): the biological pollution of the Asiatic clam Corbicula fluminea (Müller, 1774)
}

\author{
Daniele Paganelli*, Gaia Zampolini and Renato Sconfietti \\ Department of Earth and Environmental Sciences, University of Pavia, Via S. Epifanio 14, 27100 Pavia, Italy. \\ * Corresponding author: daniele.paganelli@unipv.it
}

Received: 13/10/16 Accepted: 24/03/17

\begin{abstract}
Case study of the Vernavola Stream (sub-lacustrine Ticino River basin, Northern Italy): the biological pollution of the Asiatic clam Corbicula fluminea (Müller, 1774)

The Asiatic clam, Corbicula fluminea, is among the eleven benthic species with the highest impact in the DAISIE list (DAISIE - Delivering Alien Invasive Species Inventories for Europe) because it has both environmental and socio-economic impacts. This paper reports the distribution and the dynamics of a well-established population of the alien bivalve Corbicula fluminea in the Vernavola Stream, a left-side tributary of the sub-lacustrine Ticino River (Pavia, Northern Italy). Additionally, we performed a laboratory experiment to investigate the substrate preference of the invasive bivalve, testing three different types of substrate: medium gravel, fine gravel and medium sand. The highest density of the Asiatic clam was registered in the parts of the stream where the bottom was mainly composed of sand mixed with fine gravel. The results of the experiment indicated a strong preference for sand over other substrates. In order to assess the future development of biological pollution from the Asiatic clam Corbicula fluminea, it would be useful to increase our knowledge of its autoecology and to constantly monitor its population dynamics.
\end{abstract}

Key words: biological invasion; freshwater bivalve; population structure; substrate preference; macrobenthos

\section{RESUMEN}

Estudio del arroyo Vernavola (sub-cuenca del río Ticino, norte de Italia): contaminación biológica de la almeja asiática Corbicula fluminea (Müller, 1774)

La almeja asiática, Corbicula fluminea, es una de las once especies bentónicas de mayor impacto según la lista DAISIE (DAISIE - Delivering Alien Invasive Species Inventories for Europe), debido a su impacto tanto ambiental como socioeconómico. Este artículo describe la distribución y la dinámica de una población bien establecida del bivalvo exótico Corbicula fluminea en el arroyo Vernavola, un afluente de la parte derecha del río Ticino (Pavía, norte de Italia). Además, se realizó un experimento de laboratorio para investigar la preferencia de sustrato de este bivalvo, probando tres tipos diferentes: grava media, grava fina y arena media. La mayor densidad de la almeja asiática se registró en las partes del arroyo donde el fondo estaba compuesto principalmente de arena mezclada con grava fina. Los resultados del experimento indicaron una fuerte preferencia por la arena sobre otros sustratos. Con el fin de evaluar en el futuro la contaminación biológica de la almeja asiática Corbicula fluminea, sería útil conocer más su autoecología y controlar constantemente la dinámica de su población.

Palabras clave: invasión biológica; bivalvos de agua dulce; estructura de la población; preferencia de sustrato; macrobentos 


\section{INTRODUCTION}

Biological invasion has increased in recent years, mainly due to human activities such as aquaculture, international ship traffic or, in the case of some freshwater water bodies, as a result of connecting rivers by artificial canals (Müller $e t$ al., 2002; Bij de Vaate et al., 2002). Although most introduced species do not constitute stable populations in new environments, some of them become invasive, thus causing environmental and/or socio-economic impacts (Vilà et al., 2010; Laverty et al., 2015). The result is that invasive species may change the ecosystems that they are introduced into, which is one of the most serious problems from an ecological point of view (Sala et al., 2000; Cox, 2004; Sousa et al., 2014).

Once established in a new freshwater ecosystem, most invasive species are nearly impossible to eradicate, and in the absence of biogeographic barriers, they can easily spread to other nearby naturally or artificially connected freshwater ecosystems (Havel et al., 2015).

Among the various taxonomic groups that have been introduced into freshwater ecosystems, bivalves have caused some of the most important, well-documented ecological and economic impacts (Sousa et al., 2014; Bódis et al., 2016).

One of these invasive bivalves is the Asiatic clam Corbicula fluminea (Veneroida: Corbiculidae) (Müller, 1774), a well-known exotic species native to southern and eastern Asia, among the 100 worst invasive species in Europe (DAISIE Delivering Alien Invasive Species Inventories for Europe - http://www.europe-aliens.org). Moreover, according to the Generic Impact Scoring System (GISS) (Nentwig et al., 2010), which is a method that quantifies the impact and ranking of an alien species, $C$. fluminea is considered to be one of the eleven benthic species with the highest impact in the DAISIE list (Laverty et al., 2015).

Due to the high reproduction capacity of $C$. fluminea (>68 000 pediveligers adult/year), the introduction of a single individual into freshwater environments may be sufficient to start a new population and, depending on its population density, it can cause several economic and ecological impacts (Pimentel et al., 2005; Karatayev et al., 2007; Sousa et al., 2014), such as habitat reduction for other native bivalves (Bódis et al., 2016) and the over-exploitation of environmental resources (Vaughn \& Hakenkamp, 2001). For example, the high density of $C$. fluminea can filter most of the algae from the water column, leaving little food for pelagic zooplankton (Strayer, 2010) and increasing light for vascular plants. Furthermore, as highlighted by Bódis et al. (2014), high abundance of empty shells can reduce the current velocity near the bottom, thus increasing the morphological diversity of the habitat followed by an increase of density, biomass and number of benthic species (Ilarri et al., 2012).

Nowadays, the Asiatic clam has spread to almost all the countries in Europe (Araujo et al., 1993).

In Italy, the first record of $C$. fluminea in the Ticino River was in 2003 (Bodon et al., 2005). Subsequently, in 2008, its presence was also reported for the first time in the Vernavola Stream, one of the left-bank tributaries of the Ticino River in the province of Pavia (CEMAV, 2008).

The Vernavola Stream is part of the complex irrigation system of the sub-lacustrine Ticino River, and it is also an important ecological connection between sites of ecological relevance around the urban area of Pavia, representing a Greenway for fauna, especially aquatic birds.

The Asiatic clam's colonization of the industrial water systems is well documented but, in contrast, information about the impact of this alien species on the irrigation systems is scarce. Obviously, the irrigation systems are important from an agricultural point of view, but they also play an important role from an ecological point of view because they improve the environmental variability, providing suitable habitats for the flora and fauna, especially in an anthropogenic area such as the Ticino River valley.

Considering this discovery and the invasive behaviour of the Asiatic clam, (I) we studied its distribution along the entire course of the Vernavola Stream, and (II) after identifying the area of the stream with the highest density of this species, we performed a twelve-month survey in order to obtain information on its size class distribution; (III) we then performed a laboratory experiment in order to investigate whether the invasive bivalve 


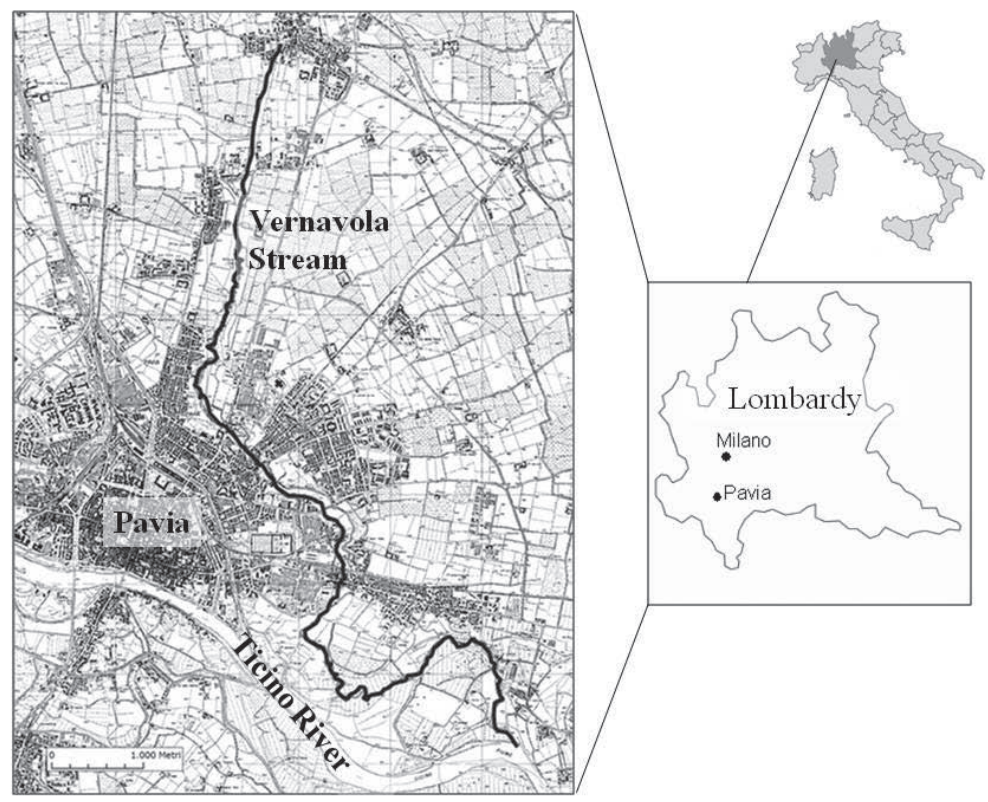

Figure 1. The entire course of the Vernavola Stream, a left-bank tributary of the south part of the sub-lacustrine Ticino River. Recorrido completo del arroyo Vernavola, un afluente, en la ribera izquierda de la parte sur, del río sub-lacustre Ticino.

can actively select the substrate where it can live, increasing our knowledge of its autoecology and providing additional information on the invasion process of other nearby freshwater habitats.

\section{MATERIALS AND METHODS}

\section{Study area}

The Vernavola Stream is one of the left-bank tributaries of the southern part of the sub-lacustrine Ticino River and it originated from the conjunction of three small streams in the northern area of Pavia (Lombardy, Northern Italy) (Fig. 1). This stream, which is $15 \mathrm{~km}$ long and an average of $7 \mathrm{~m}$ wide, represents an important ecological connection between several Sites of Community Importance (SCI, Directive 92/43/EEC) located above the city of Pavia, and the green corridor of the Ticino and Po rivers in the south of Pavia.

Despite being small, the Vernavola Stream has all the typical characteristics of a plain river: stretches of the stream are surrounded by agricultural fields with anthropogenic remodelling of the banks, the central part of the stream flows through an urban park and the city centre of Pavia, and its final stretches flow through natural areas, such as oxbow lakes and terrace springs, mixed with agricultural fields where the stream reaches the Ticino River. The stream is characterised by a moderate flow, and the bottom is mainly composed of coarse and fine sand, mixed with gravel and silt (Pesci \& Sconfietti, 2009).

\section{Field survey}

In February 2013, in order to define the distribution and population density of Corbicula fluminea in the Vernavola Stream, we selected 9 stations along the entire course of the stream (one every $1.5 \mathrm{~km}$ ). In each station, we selected a $20 \mathrm{~m}$ transect displaying a homogeneous habitat suitable for bivalves, and along this transect we collected four sub-samples (one every $5 \mathrm{~m}$ ) by means of a sampling net (1 mm mesh) within a $50 \times 25 \mathrm{~cm}$ frame, which corresponds to an area of $0.125 \mathrm{~m}^{2}$. In order to estimate the density (ind $/ \mathrm{m}^{2}$ ), the total number of collected specimens $(\mathrm{N})$ was divided by the total sampled area $\left(0.5 \mathrm{~m}^{2}\right)$.

Subsequently, in the area of the stream where 
C. fluminea showed its highest density, we performed a monthly biological survey (from February 2014 to January 2015) following the previous experimental design. Unfortunately, due to an unexpected problem, we cannot show population data collected in June and July 2014. We also recorded temperature, $\mathrm{pH}$, and percentage of oxygen saturation by means of a multiparametric probe HACH-HQ40.

In the laboratory, we then measured the shell length $(\mathrm{L}, \mathrm{mm})$ of each specimen with a clock calliper $(0.02 \mathrm{~mm})$ in order to obtain a size class distribution classifying all specimens into six size classes: $\mathrm{I} \rightarrow<5 \mathrm{~mm}$; II $\rightarrow 5-10 \mathrm{~mm}$; III $\rightarrow>10-15$ $\mathrm{mm} ; \mathrm{IV} \rightarrow>15-20 \mathrm{~mm} ; \mathrm{V} \rightarrow>20-25 \mathrm{~mm}$; VI $\rightarrow>25$ $\mathrm{mm}$.

\section{Laboratory experimental designs}

We used a total of 1800 specimens (15-25 mm length) that were collected from the area of the stream where $C$. fluminea showed its highest density and then acclimatised in tap water at 20 ${ }^{\circ} \mathrm{C}$ in the laboratory for 7 days, and three different types of substrates: medium gravel (MG, diameter $>5 \mathrm{~mm}$ ), fine gravel (FG, diameter $5-2 \mathrm{~mm}$ ) and medium sand (MS, diameter 0.25-0.5 mm).

Half of the specimens were placed in 90 experimental units (EU: 30x24x9 $\mathrm{cm}$ ) with a single substrate as a control, while the remaining specimens were placed in another 90 experimental units with all possible combinations of the three different substrates. For each EU, 10 specimens were positioned in a row on the boundary between two different substrates: 5 of them were positioned on the right valve and 5 on the left valve, in order to minimise the effect of the orientation of the mollusc during its choice.

In all the trials of the experiment, we observed that after 10 minutes only $38 \%$ of the specimens had actively made a substrate preference, after 20 minutes more than $60 \%$ of the specimens had moved to one substrate, and within 1 hour $89 \%$ of the specimens had moved. According to these observations, we decided to stop the experiment after 1 hour and then we counted the number of specimens for each substratum in order to detect whether $C$. fluminea showed an active preference for a particular substrate.

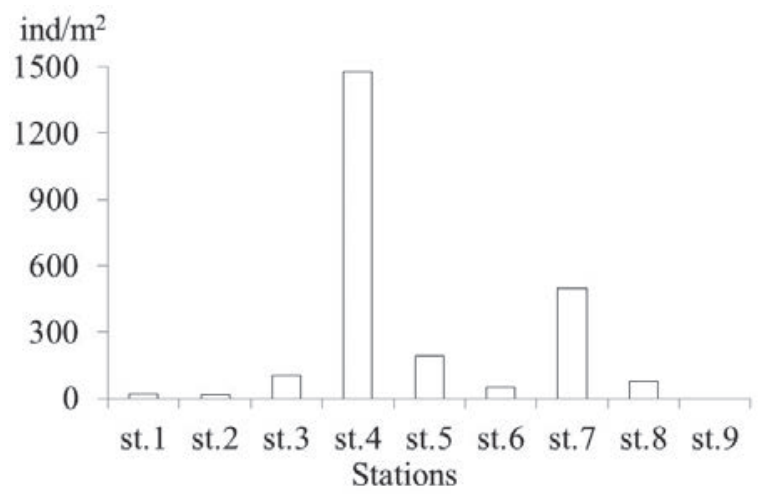

Figure 2. Density of Corbicula fluminea (ind $/ \mathrm{m}^{2}$ ) in 2013 from upstream (st. 1) to downstream (st. 9) of the Vernavola Stream. Densidad de Corbicula fluminea (ind $/ \mathrm{m}^{2}$ ) en 2013, desde la parte alta (st. 1) hasta la parte baja (st. 9) del arroyo Vernavola.

\section{Statistical analyses}

Population abundance and substrate selection results were investigated through a General Linear Model analysis (GLM), an ANOVA procedure in which the calculations are performed using a least squares regression approach to describe the statistical relationship between one or more predictors and a continuous response variable.

Anderson-Darling and Bartlett tests were used prior to GLM to check the normality of data and the homogeneity of variance. However, when homogeneity of variance was not achieved, data were analysed nonetheless, as analysis of variance is considered robust enough when there are many independent replicates and sample sizes are equal (Underwood, 1997).

Finally, pairwise Tukey post hoc tests were performed in order to determine which set of data mainly contribute to the differences found by GLM.

All the statistical analyses were performed using MINITAB 16 software package.

\section{RESULTS}

Distribution and population dynamic of Corbicula fluminea in the Vernavola Stream

Considering all 9 stations sampled in 2013 in the Vernavola Stream, the mean density ( \pm standard deviation) of Corbicula fluminea was 


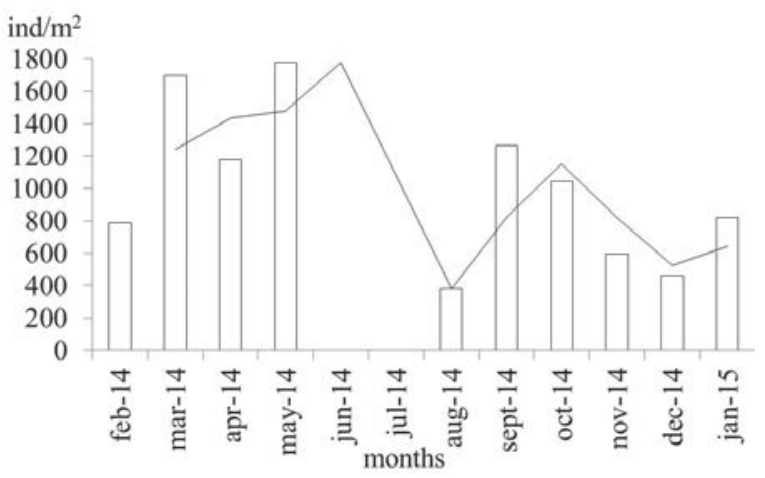

Figure 3. Density of Corbicula fluminea collected in station 4 from February 2014 to January 2015. The black line indicates the moving averages in the two periods. Densidad de Corbicula fluminea muestreada en la estación 4, desde febrero de 2014 hasta enero de 2015. La línea negra indica las medias móviles en los dos períodos.

$269.68 \pm 478.6 \mathrm{ind} . / \mathrm{m}^{2}$. The highest densities of the Asiatic clam were registered in station 4 (1478 ind $\left./ \mathrm{m}^{2}\right)$, station 7 (498 ind $\left./ \mathrm{m}^{2}\right)$ and station 5 (190 ind $/ \mathrm{m}^{2}$ ); on the contrary, we did not find any bivalves in station 9 (Fig. 2).

From February 2014 to January 2015, the water temperature varied from a minimum value of $9.6^{\circ} \mathrm{C}$ in January 2015 to a maximum value of $19.6^{\circ} \mathrm{C}$ in August 2014; the percentage of oxygen saturation was always undersaturated, except in April 2014 when it reached $136.3 \%$, and the annual mean $\mathrm{pH}$ value was $7.3 \pm 0.55$.

The mean density ( \pm standard deviation) of the Asiatic clam registered during the twelve-month survey in station 4 was $1000 \pm 483 \mathrm{ind} / \mathrm{m}^{2}$, with the highest value registered in May (1778 ind $/ \mathrm{m}^{2}$ ) and the lowest in August (382 ind $\left./ \mathrm{m}^{2}\right)(\mathrm{DF}=9$; $\mathrm{F}=5.06 ; p<0.001$ ) (Fig. 3).

The length size-class distribution analysis of the specimens over the whole year showed that small bivalves, with shell length $\mathrm{L}<10 \mathrm{~mm}$, were collected in spring (March-April 2014) and in winter (December 2014-January 2015), while bivalves with $\mathrm{L}>10 \mathrm{~mm}$ were collected during late summer and autumn (August-November 2014) $(\mathrm{DF}=9$; $\mathrm{F}=61.57 ; p<0.001)$ (Fig. 4).

\section{Experimental results}

Out of the 900 specimens used in the control experiment, $52.8 \%$ moved to their left while 36.8
$\%$ decided to move to their right; the remaining $10.4 \%$ did not move to either side. The difference between the side they moved to was tested by means of GLM analysis and the results were not statistically significant ( $\mathrm{DF}=1 ; \mathrm{F}=1.67 ; p: 0.226)$; thus, following this result, we performed an experiment in order to define whether Corbicula fluminea can actively prefer one substrate over another.

In the first trial of the experiment, where we compared medium and fine gravel as substrates, we discovered that $69.3 \%$ of the total specimens
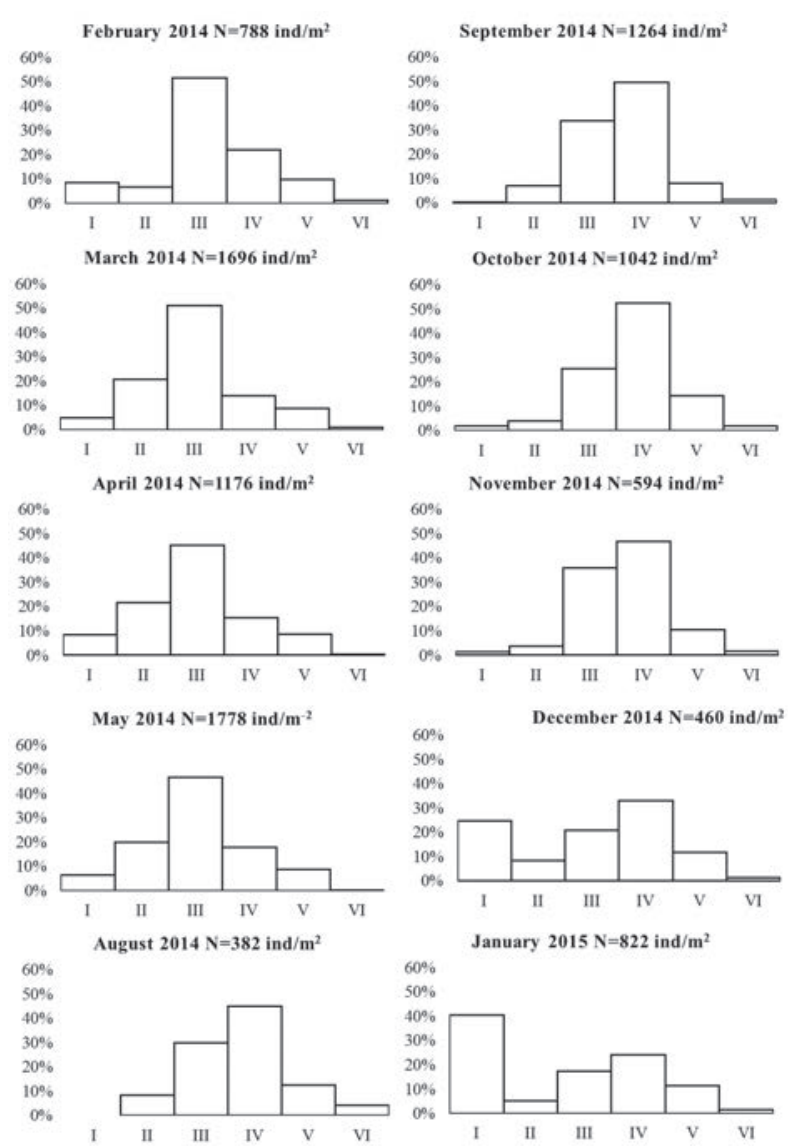

Figure 4. Size class distribution of Corbicula fluminea in the Vernavola Stream between February 2014 and January 2015. Size classes: $\mathrm{I} \rightarrow<5 \mathrm{~mm}$; II $\rightarrow 5-10 \mathrm{~mm}$; III $\rightarrow>10-15 \mathrm{~mm}$; IV $\rightarrow$ $>15-20 \mathrm{~mm} ; \mathrm{V} \rightarrow>20-25 \mathrm{~mm} ; \mathrm{VI} \rightarrow>25 \mathrm{~mm}$. N: total number of specimens collected in one $\mathrm{m}^{2}$. Distribución de clases de tamaño de Corbicula fluminea en el arroyo Vernavola, entre febrero de 2014 y enero de 2015. Clases de tamaño: $I \rightarrow<5$ $\mathrm{mm} ; \mathrm{II} \rightarrow 5$ - $10 \mathrm{~mm} ; \mathrm{III} \rightarrow>10-15 \mathrm{~mm} ; \mathrm{IV} \rightarrow>15-20 \mathrm{~mm} ; \mathrm{V}$ $\rightarrow>20-25 \mathrm{~mm} ; V I \rightarrow>25 \mathrm{~mm}$. N: número total de especimenes recogidos en un $\mathrm{m}^{2}$. 


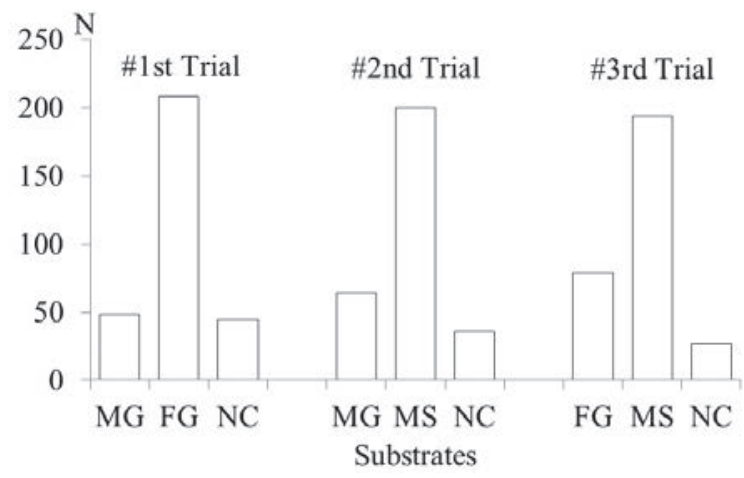

Figure 5. Results of the three trials of the experiment. MG: medium gravel; FG: fine gravel; MS: medium sand; NC: no choice. N: number of Corbicula fluminea specimens. Resultados de los tres ensayos del experimento. MG: grava media; FG: grava fina; MS: arena media; NC: ninguna opción. $N$ : número de especímenes de Corbicula fluminea.

preferred fine gravel while $16 \%$ preferred medium gravel; $14.7 \%$ did not choose either substrate.

In the second trial, where we compared medium gravel and medium sand, we discovered that $66.7 \%$ of the specimens preferred medium sand while $21.3 \%$ preferred medium gravel; 12 $\%$ did not choose either substrate.
For the third and final trial, where we compared fine gravel and medium sand, we discovered that $64.66 \%$ of the specimens preferred medium sand while $26.34 \%$ preferred fine gravel; only $9 \%$ of the total did not actively move to either substrate (Fig. 5).

These differences were confirmed by GLM analyses and Tukey tests (Table 1).

\section{DISCUSSION}

It is well-known that Corbicula fluminea is able to colonise freshwater ecosystems (Lucy et al., 2012), and this Asiatic clam has now become well-established in almost all the water bodies in northern Italy (Ciutti et al., 2007; Pezzi, 2008; Ciutti \& Cappelletti, 2009). For example, in one study performed in Lake Maggiore, its density reached $1249 \mathrm{ind} / \mathrm{m}^{2}$ (Kamburska et al., 2013), and in another study performed in the Ticino River, its density was almost 200 ind $/ \mathrm{m}^{2}$ (Nicolini \& Lodola, 2011). In the Vernavola Stream, its density reached almost $1500 \mathrm{ind} / \mathrm{m}^{2}$ (in station 4, Fig. 3), which is comparable to the level in Lake Maggiore.

Moreover, results of population dynamics

Table 1. GLM and Tukey test results of the experiment between different substrate types: medium gravel (MG), fine gravel (FG) and medium sand (MS). No choice is indicated by NC. Resultados del test GLM y Tukey del experimento entre diferentes tipos de sustratos: grava mediana (MG), grava fina (FG) y arena media (MS). NC indica que ninguna opción fue seleccionada.

\begin{tabular}{|c|c|c|c|c|}
\hline Trials & GLM & & Tukey tests & \\
\hline \multirow{3}{*}{$\# 1:$ MG - FG - NC } & \multirow{3}{*}{$\begin{array}{c}\mathrm{DF}=2 \mathrm{~F}=103.79 \\
p<0.001\end{array}$} & MG vs FG & MG vs NC & FG vs NC \\
\hline & & $\mathrm{T}=12.32$ & $\mathrm{~T}=-0.308$ & $\mathrm{~T}=-12.63$ \\
\hline & & $p<0.001$ & $p: 0.94$ & $p<0.001$ \\
\hline \multirow{3}{*}{ \#2: MG - MS - NC } & \multirow{3}{*}{$\begin{array}{c}\mathrm{DF}=2 \mathrm{~F}=91.12 \\
p<0.001\end{array}$} & MG vs MS & MG vs NC & MS vs NC \\
\hline & & $\mathrm{T}=10.46$ & $\mathrm{~T}=-2.15$ & $\mathrm{~T}=-12.62$ \\
\hline & & $p<0.001$ & $p: 0.085$ & $p<0.001$ \\
\hline \multirow{3}{*}{ \#3: FG - MS - NC } & \multirow{3}{*}{$\begin{array}{c}\mathrm{DF}=2 \mathrm{~F}=98.44 \\
p<0.001\end{array}$} & FG vs MS & FG vs NC & MS vs NC \\
\hline & & $\mathrm{T}=9.44$ & $\mathrm{~T}=-4.27$ & $\mathrm{~T}=-13.71$ \\
\hline & & $p<0.001$ & $p<0.001$ & $p<0.001$ \\
\hline
\end{tabular}


showed a high density during the first part of the year (February 2014-May 2014) after the first reproductive period, and a general decrease from August 2014 to January 2015. Even though we cannot show population data collected in June and July 2014, the density estimated up to May was definitely higher than that estimated from August 2014 to January 2015.

One of the main environmental characteristics that favours the high abundance of this bivalve is the presence of a suitable substrate. The relationship between $C$. fluminea and substrate composition was previously highlighted by Nicolini \& Lodola (2011), Bódis et al. (2012) and Kamburska et al. (2013), who found higher densities in sandy substrates.

Overall, our data shows that fine gravel is significantly preferred over medium gravel, but medium sand is significantly preferred over fine gravel. Moreover, during the first trial of the experiment (fine gravel versus medium gravel), we observed a higher number of "undecided" specimens $(\mathrm{NC}=44)$; in this case, Tukey tests indicated that there was no statistical difference between the number of "undecided" specimens and the number of specimens which preferred medium gravel. This could suggest that Corbicula specimens are not very well-suited to this substrate.

In contrast, the lowest number of "undecided" specimens was registered in the last trial when we tested the preference between medium sand and fine gravel. Thus, we can hypothesise that medium sand may be the perfect substrate for Corbicula fluminea.

These findings are also in accordance with Belanger et al. (1985) and Schmidlin \& Baur (2007), who stated that $C$. fluminea prefers a fine substrate, high nutrient level in the water, warm water temperature and relatively low water current.

\section{CONCLUSIONS}

The invasion of the Vernavola Stream began in 2008, but due to its low industrial value, it is difficult to hypothesise whether the high abundance of $C$. fluminea may have caused any economic impacts in this area. On the other hand, it may have caused a high ecological impact on the autochthonous mollusc assemblages, but there is no previous information about the autochthonous mollusc assemblages of the Vernavola Stream so we cannot be sure whether the presence of the Asiatic clam has led to a reduction of the autochthonous community.

According to the high density recorded along almost the entire course of the Vernavola Stream, we can affirm that $C$. fluminea is a well-established species in this water body. One of the main reasons for this invasion may be the presence of a suitable environmental combination such as fine substrate mixed with fine gravel, high nutrient level and relatively low water current.

Moreover, the preference for fine substrates is also confirmed by our laboratory experiments: they make it easy for bivalves to dig into the bottom. On the contrary, in the presence of medium/coarse substrates, is more difficult for them to dig into the bottom and the level of colonisation is therefore very low. This hypothesis is also confirmed by our data on the distribution of $C$. fluminea along the course of the Vernavola: at the end of the stream, where the bottom is composed of gravel, the Asiatic clam is completely absent.

In conclusion, even though the presence of Corbicula fluminea is already well-documented in Europe and Italy, it is important to both increase our knowledge of the ecological preferences of Corbicula fluminea (such as its substrate preferences) and constantly monitor its population dynamics in invaded areas in order to assess its biological pollution in the future.

\section{ACKNOWLEDGMENTS}

We would like to thank Charlotte Buckmaster for revising the English text and Dr. Jasmine Ferrario for translating the Spanish text.

\section{REFERENCES}

ARAUJO, R., D. MORENO \& M.A. RAMOS. 1993. The asiatic clam Corbicula fluminea (Müller, 1774) (Bivalvia: Corbiculidae) in Europe. American Malacological Bulletin 10: 39-49.

BELANGER, S.E., J.L. FARRIS, D.S. CHERRY 
\& J.J. CAIRNS. 1985. Sediment preference of the freshwater asiatic clam, Corbicula fluminea. Nautilus 99: 66-73.

BIJ DE VAATE, A., K. JAZDZEWSKI, H. KETELAARS, S. GOLLASH \& G. VAN DER VELDE. 2002. Geographical patterns in range extension of Ponto-Caspian macroinvertebrates species in Europe. Canadian Journal of Fish and Aquatic Science 59: 1159-1174. DOI: 10.1139/F02-098

BÓDIS, E., C. SIPKAY, B. TÓTH, N. OERTEL, J. NOSEK \& E. HORNUNG. 2012. Spatial and temporal variation in biomass and size structure of Corbicula fluminea in Danube River catchment, Hungary. Biologia 67: 739-750. DOI: 10.2478/s11756-012-0062-5

BÓDIS, E., B. TÓTH, J. SZEKERES, B. BORZ \& R. SOUSA. 2014. Empty native and invasive bivalve shells as benthic habitat modifiers in a large river. Limnologica 49: 1-9. DOI: 10.1016/j.limno.2014.07.002

BÓDIS, E., B. TÓTH \& SOUSA R. 2016. Freshwater mollusc assemblages and habitat associations in the Danube River drainage, Hungary. Aquatic Conservation: Marine and Freshwater Ecosystems 26 (2): 319-332. DOI: 10.1002/ aqc. 2585

BODON, M., S. CIANFANELLI, G. MANGANELLI, L. CASTAGNOLO, E. PEZZOLI \& F. GIUSTI. 2005. Mollusca Bivalvia. Checklist e distribuzione della fauna italiana. 10.000 specie terrestri e delle acque interne. Memorie del Museo Civico di Storia Naturale di Verona.

CEMAV. 2008. Newsletter del CEMAV 1(3): 1-8

CIUTTI, F., A. GIROUD \& M. MARIANI. 2007. Considerazioni su una popolazione di Corbicula fluminea (Müller, 1774) nel Lago di Garda sud-orientale (Italia). Natura Bresciana 35: 121-124.

CIUTTI, F., C. CAPPELLETTI. 2009. First record of Corbicula fluminalis (Müller, 1774) in Lake Garda (Italy), living in sympatry with Corbicula fluminea (Müller, 1774). Journal of Limnology 68: 162-165. DOI: 10.4081/ limnol.2009.162

COX, G.W. 2004. Alien Species and Evolution. Island Press. Washington.

HAVEL, J.E., K.E. KOVALENKO, S.M.
THOMAZ, S. AMALFITANO \& L.B. KATS. 2015. Aquatic invasive species: challenges for the future. Hydrobiologia 750: 147-170. DOI: 10.1007/s10750-014-2166-0

ILARRI, M., F. FREITAS, S. COSTA DIAS, C. ANTUNES, L. GUILHERMINO \& R. SOUSA 2012. Associated zoo benthos with the invasive Asian clam Corbicula fluminea. Journal of Sea Research 72: 113-120. DOI: 10.1016/j.seares.2011.10.002

KAMBURSKA, L., R. LAUCERI, M. BELTRAMI, A. BOGGERO, A. CARDECCIA, I. GUARNERI, M. MANCA \& N. RICCARDI. 2013. Establishment of Corbicula fluminea (O.F. Müller, 1774) in Lake Maggiore: a spatial approach to trace the invasion dynamics. BioInvasions Records 2: 105-117. DOI: 10.3391/bir.2013.2.2.03

KARATAYEV, A.Y., D.K. PADILLA, D. MINCHIN, D. BOLTOVSKOY \& L.E. BURLAKOVA. 2007. Changes in global economies and trade: the potential spread of exotic freshwater bivalves. Biological Invasion 9: 161-180. DOI: 10.1007/s10530-0069013-9

LAVERTY, C., W. NENTWIG, J.T.A. DICK \& F. LUCY. 2015. Alien aquatics in Europe: assessing the relative environmental and socio-economic impacts of invasive aquatic macroinvertebrates and other taxa. Management of Biological Invasions 6 (4): 341-350.

LUCY, F.E., A. KARATAYEV, L. BURLAKOVA. 2012. Prediction for the spread, population density, and impacts of Corbicula fluminea in Ireland. Aquatic Invasions 7: 465-474. http://dx.doi.org/10.3391/ai.2012.7. 4.003

MÜLLER, J.C., D. HIDDE \& A. SEITZ. 2002. Canal construction destroys the barriers between major European invasion lineages of the zebra mussel. Proceeding of Royal Society Biological Sciences 269 (1496): 1139-1142. DOI: $10.1098 / \mathrm{rspb} .2002 .1994$

NENTWIG, W., E. KÜHNEL \& S. BACHER. 2010. A generic impact-scoring system applied to alien mammals in Europe. Conservation Biology 24: 302-311. DOI: 10.1111/ j.1523-1739.2009.01289.x

NICOLINI, L., A. LODOLA. 2011. Densità di 
popolazione e biometria di Corbicula fluminea (Müller, 1774), bivalve alloctono invasivo nel fiume Ticino (Pavia). Acta Biologica 89: 145-147.

PESCI, I. \& R. SCONFIETTI. 2009. La roggia Vernavola a Pavia: sentieri didattici, valorizzazione e tutela del paesaggio. Acta Biologica 86: 75-76.

PEZZI, M. 2008. Prima segnalazione di Corbicula fluminea (O.F. Müller, 1774) nel fiume Senio (Provincia di Ravenna) (Mollusca, Bivalvia, Corbiculidae). Quaderni della Stazione di Ecologia 18: 89-92.

PIMENTEL, D., R. ZUNIGA \& D. MORRISON. 2005. Update on the environmental and economic costs associated with alien-invasive species in the United States. Ecological Economics 52: 273-288. https://doi.org/10. 1016/j.ecolecon.2004.10.002

SALA, O.E., F.S CHAPIN, J.J. ARMESTO, E. BERLOW, J. BLOOMFIELD, R. DIRZO, E. HUBER-SANWALD, L.F. HUENNEKE, R.B. JACKSON, A. KINZIG, R. LEEMANS, D.M. LODGE, H.A. MOONEY, M. OESTERHELD, N.L. POFF, M.T. SYKES, B.H. WALKER, M. WALKER \& D.H. WALL. 2000. Global biodiversity scenarios for the year 2100. Science 287: 1770-1774. DOI: 10.1126/science.287.5459.1770

SCHEFFER, M. 2009. Critical transitions in nature and society. Princeton University press. Princeton.

SCHMIDLIN, S. \& B. BAUR. 2007. Distribution and substrate preference of the invasive clam
Corbicula fluminea in the river Rhine in the region of Basel (Switzerland, Germany, France). Aquatic Sciences 69: 153-161. DOI: https://doi.org/10.1007/s00027-006-0865-y

SOUSA, R., NOVAIS A., COSTA R. \& D. STRAYER 2014. Invasive bivalves in fresh waters: impacts from individuals to ecosystems and possible control strategies. Hydrobiologia 735: 233-251. https://doi.org/10.1007/s10750012-1409-1

STRAYER, D.L., 2010. Alien species in fresh waters: ecological effects, interactions with other 470 stressors, and prospects for the future. Freshwater Biology 55: 152-174. DOI: 10.1111/j.1365-2427.2009.02380.x

UNDERWOOD, A.J. 1997. Experiments in Ecology: Their Logical Design and Interpretation Using Analysis of Variance. Cambridge University Press. Cambridge.

VAUGHN, C.C. \& C.C. HAKENKAMP. 2001. The functional role of burrowing bivalves in freshwater ecosystems. Freshwater Biology 46: 1431-1446. DOI: 10.1046/j.1365-2427. 2001.00771.x

VILÀ, M., C. BASNOU, P. PYŠEK, M. JOSEFSSON, P. GENOVESI, S. GOLLASCH, W. NENTWIG, S. OLENIN, A. ROQUES, D. ROY \& P.E. HULME. 2010. How well do we understand the impacts of alien species on ecosystem services? A pan-European, cross-taxa assessment. Frontiers in Ecology and the Environment 8: 135-144. DOI: 10.1890/080083 